\title{
GUERRILLA MARKETING CONCEPT AND FURTHER RESEARCH POSSIBILITIES
}

\author{
[Pojem guerilla marketing a další možnosti výzkumu] \\ Martin Klepek ${ }^{1}$ \\ ${ }^{1}$ Silesian University in Opava, School of Business Administration in Karvina,, Univerzitní nám. 1934/3 \\ 73340 Karviná \\ Email:klepek@opf.slu.cz
}

\begin{abstract}
In these days of informational overload the importance of effective communication from company to consumer is essential. Yet many firms hardly find a proper way to step out from informational fog. There are some unusual tools for marketing managers as social media marketing, viral marketing, buzzmarketing, neuromarketing and so on, which offer opportunities to differentiate. Guerrilla marketing, as one of them, unfortunately suffers of theoretical ambiguity. This paper has two main objectives. Firstly, it aims to provide an analysis of the current state of theoretical knowledge about guerrilla marketing and show basic concepts and thoughts in this particular field. Secondly, based on previous analysis, it focuses on selecting gaps in the current knowledge and suggests paths for the future research. This could help to provide relevant material for both the marketing scholars and marketing managers or executives.
\end{abstract}

Keywords: co-word analysis, communication mix, guerrilla marketing, marketing communication, marketing strategy, innovative marketing.

JEL classification: M31

Doručeno redakci: 23.2.2014; Recenzováno: 7.5.2014; 17.5.2014; Schváleno k publikování: 23.9.2014

\section{Introduction}

Nowadays, companies have more instruments to do effective marketing communication than ever before. Unfortunately, at the same time there are more threats which make this effort a highly sophisticated problem. One of the biggest threats is informational overload, customer conscious attention - either to product or company itself, low brand loyalty and diminishing effectiveness of classical advertising techniques.

The first attempt to find evidence about influence of overload on consumer decision making was described by Malhotra (1982a). Since that time many years have passed and many changes have occurred. Today consumer has to face thousands of commercial messages a day and decision making under this pressure is even worse. Thanks to worldwide spreading of information technologies and mass media commerce, it is hard to find space for an undisturbed dialogue with client.

There are other problems such as low conscious attention, low brand loyalty and diminishing effectiveness of television advertising these days. Firstly, conscious attention to companies' communication mix is practically rare (Lindström 2012). Customers demonstrate lower brand loyalty and greater willingness to switch between brands (Roy and Chattopadhyay 2010). Moreover, effectiveness of traditional forms of advertising is constantly decreasing (Kaikati and Kaikati 2004, Smith et al. 2007). Under these circumstances, companies have to reconsider their approach to communication strategies.

Recent global financial crisis puts pressure on companies marketing budgets and even big companies have to think out new options to differentiate. One of many ways to differentiate is 
unique marketing approach (Porter 1985). This could lead to sustainable competitive advantage in the highly competitive global market place. Adopting unconventional form of marketing could lead to higher risk. Analogically to Ansoff growth matrix, when company enters unknown territory (in diversification vector, it is new product and new market) it is usually associated with a higher risk rate (Ansoff 1965). However in case of marketing approach in the present dynamic environment it is riskier not to take any risk at all.

The development described above enabled guerrilla marketing to step into a marketing practice worldwide. While guerrilla marketing activities can be seen more and more in practice, the phenomenon is either discussed very controversially in the marketing science or even neglected completely in the scientific marketing literature (Nufer 2013, Hutter and Hoffmann 2011). There is a strong rising aversion to traditional advertising which can be overcome by this unconventional approach. Important challenge for scholars is to deliver proper theoretical fundamentals and hence limit later practical misuse.

\section{From the beginning to current state of knowledge}

If we want to speak about guerrilla marketing literature we simply have to mention Conrad Jay Levinson, the author of the book Guerrilla marketing (1984). He is the creator of guerrilla marketing concept which implies unconventional way of putting promotion activities on very low budget. Levinson is rightly called the "father" of guerrilla marketing and his book has undergone many editions.

Advertising agencies and practitioners also designated their concepts and thoughts over the years. Consequently, more and more forms of unconventional advertising techniques are identified by marketing literature. We can mention stealth marketing, bait-and-tease marketing, brand pusher, celebrity marketing, marketing in pop and rap music, marketing in video games, viral marketing, events, buzz marketing, ambush marketing, ambient marketing (Kaikati and Kaikati 2004, Hughes 2006, Egan 2007, Mughari 2010). However, we can describe most of it as similar to guerrilla marketing.

Hutter and Hoffman (2011) understand guerrilla marketing as an umbrella term for unconventional advertising campaigns which aim at drawing the attention of a large number of recipients to the advertising message at relatively little costs by evoking the surprise effect and the diffusion effect. Mughari (2010) asserts that guerrilla marketing is mentality too, because the mentality of thinking is out of the box and thinking for solutions for communication problems in a broader way, instead of thinking in terms of just TV commercials. The element of surprise may be guerrilla marketing's greatest attribute (Zuo and Veil 2007). Thus, when implementing guerrilla tactics, small size is actually an advantage (Paksoy and Chang 2010). From this point of view, it appears appropriate distinctly for small and medium-sized enterprises (SMEs) for which is low marketing budget so typical.

Hutter and Hoffman (2011) further operate with the term guerrilla effect which is more or less better expression for such activities on the marketplace. Because traditional marketing consists of marketing mix (Product, Price, Place, Promotion) and guerrilla operates mainly with promotional part, it is misleading to use the term marketing. Patalas (2009) suggests that guerrilla marketing cannot substitute classical marketing because it is rather trying to complete it properly. Consistently with this idea, Mughari (2011) conducted research of guerrilla and traditional marketing integration and its effect on productivity of organizational marketing in enterprises. Study showed that there is a relationship between the integration of guerrilla and traditional marketing and the improvement of productivity of organizational marketing in examined enterprises. 
In literature, we can find attempts to expand guerrilla effect on all aspects of marketing mix. Schulte (2007) bound the guerrilla concept to the traditional marketing mix by distributing guerrilla marketing coverage percentage as follows:

Figure 1: Guerrilla marketing and marketing mix

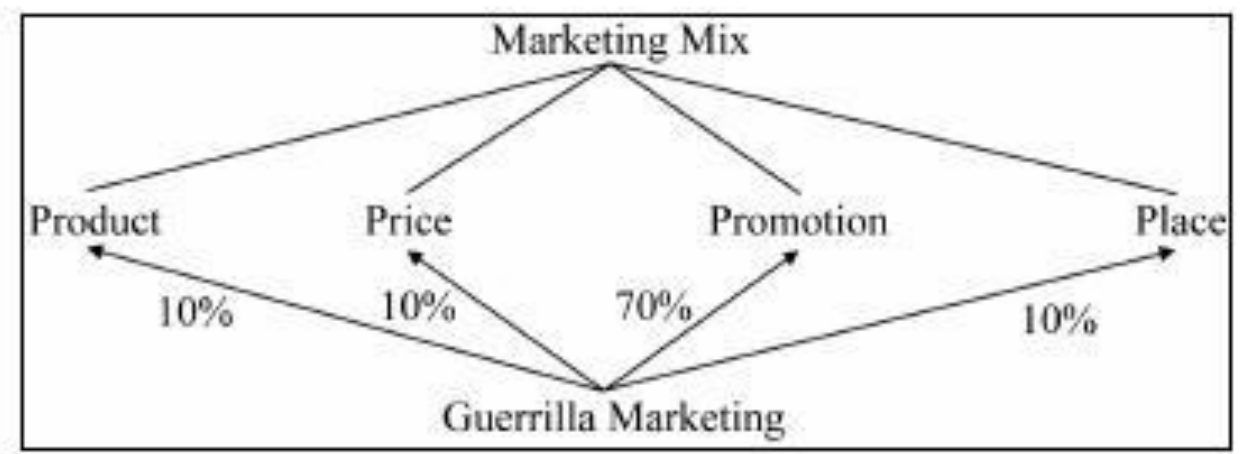

Source: NUFER, G., 2013.

Nevertheless, this understanding strengthens contradictions in marketing field. Dividing creative, smart and fresh solutions as guerrilla and the rest as traditional is fundamentally wrong. Moreover, public often equal marketing to advertising and this dividing harms understanding of marketing as a discipline. Therefore the author of this paper adopts Hutter and Hoffman (2011) guerrilla effect term as it is more complex and accurate.

Many students, practitioners and even scholars consider guerrilla marketing as a type of marketing strategy which is designed for marketing mix and mainly used in the promotion element. However, as we can see from the above theoretical brief summarization, it is rather a new form of communication technique than complex business strategy.

\section{Methods}

This review is consistent with the recent recommendations to strengthen the rigor of reviews in economic field (Tranfield et al. 2003). Therefore it consists of not only narrative, but also quantitative approach describing the current state of theoretical framework. Tranfield et al. (2003) further propos three systematic stages to ensure appropriate procedure of research shown in figure 2.

Figure 2: Stages of a systematic review

\begin{tabular}{|l|l|}
\hline Stage I & Planning the review \\
\hline Phase 0 & Identification for the need for a review \\
\hline Phase 1 & Preparation of a proposal for a review \\
\hline Phase 2 & Development of a review protocol \\
\hline Stage II & Conducting a review \\
\hline Phase 3 & Identification of research \\
\hline Phase 4 & Selection of studies \\
\hline Phase 5 & Study quality assessment \\
\hline Phase 6 & Data extraction and monitoring progress \\
\hline Phase 7 & Data synthesis \\
\hline Stage III & Reporting and dissemination \\
\hline Phase 8 & The report and recommendations \\
\hline Phase 9 & Getting evidence into practice \\
\hline
\end{tabular}

Source: TRANFIELD, D., DENYER, D. and SMART, P., 2003. 
In the planning stage the need for a review of guerrilla marketing is identified. There is only one similar previous effort to summarize and systematically describe theoretical framework by Hutter and Hoffmann (2011). The authors, however, did not use quantitative methods in their paper therefore there is certain space left for this presented paper.

In conducting stage, research focuses on the secondary data collection which is limited in some ways. Firstly, the author chooses to limit the review to the reviewed journal articles only (excluding peer-to-peer reviewed writings). These can be considered validated knowledge and are likely to have the highest impact in the field of guerrilla marketing. Secondly, after automatic filtering, the author manually went through the abstracts of the articles and eliminated non suitable candidates, for example editorials, book reviews etc. Thomson Reuters Web of Science (10) and EBSCO search engine (36) were used to collect overall 46 articles.

The titles of all the articles were prepared for analysis by modifying spellings (for example single " $r$ " in the word guerrilla in some cases; or singular and plural form) and excluding word separators. At the same time, missing keywords were added from the keywords list to a single line with a title to complete information about the articles. This procedure guaranteed the acceptation of articles which titles were more or less poetic and had complicated connection between the title and the content.

With such modified data frequency analysis was done using free license software Textstat 3.0 (http://neon.niederlandistik.fu-berlin.de/textstat/). Frequency analysis determinates set of keywords and its occurrence and also provides keyword list in order of occurrence (Ding et al. 2001). The software calculated the frequency with which consolidated words occurred across 46 titles. From the results 37 keywords were chosen (frequency $\geq 4$ ) for co-word analysis. This analysis is a content bibliometrics technique which reveals patterns in discourse by measuring the association strengths of terms representative of relevant publications produced in the corresponding field (Coulter et al. 1998). For performing co-word analysis free software TI has been used (http://www.leydesdorff.net/software/ti/index.htm).

As a support tool, histogram has been developed carrying information about article releasing frequency in particular years since 1984. Commonly known as a year when guerrilla marketing was introduced. This helps to show development of scholars' interests in the field over almost three decades. Findings are summarized in conclusion of current paper.

\section{Results}

Table 1 shows frequency analysis which revealed 37 most occurred words across articles titles and keywords. One would expect, 'marketing' (46) and 'guerrilla' (44) were the top occurred as these were the searched words. Word 'advertising' (28) was placed the third. Conversely, we can point out a word 'marketing mix' which we cannot find in the top table at all. This shows the nature of understanding of guerrilla marketing in the research field as a ' $\mathrm{P}$ ' promotion oriented which also supports the frequency of other words: 'word of mouth' (20), 'communication' (16), 'outdoor' (11), 'buzz' (6), 'public' (5), 'broadcasting' (5), 'sales promotion' (4), 'campaign' (4). 
Table 1: Frequency analysis of articles titles and keywords.

\begin{tabular}{|c|c|c|c|c|c|c|}
\hline 1. & marketing & 46 & 14. outdoor & 11 & 27. & network \\
\hline 2. & guerrilla & 44 & 15. business & 10 & 28. & broadcasting \\
\hline 3. & advertising & 28 & 16. television & 8 & 29. & stealth \\
\hline 4. & social & 24 & 17. management & 8 & 30. & sports \\
\hline 5. & consumer & 23 & 18. effectiveness & 8 & 31. & sales promotion \\
\hline 6. & word of mouth & 20 & 19. product & 7 & 32. & preferences \\
\hline 7. & services & 18 & 20. networks & 7 & 33. & opinion \\
\hline 8. & internet & 18 & 21. ethical & 7 & 34. & online \\
\hline 9. & research & 16 & 22. web & 6 & 35. & distribution \\
\hline 10 & communication & 16 & 23. buzz & 6 & 36. & campaign \\
\hline 11 & viral & 15 & 24. public & 5 & 37. & brand \\
\hline 12 & strategy & 13 & 25. psychology & 5 & & \\
\hline 13 & behavior & 13 & 26. planning & 5 & & \\
\hline
\end{tabular}

Source: Authors‘ own research.

Strategic dimension of researched topic is represented very little by the words 'strategy' (13), 'management' (8) and 'planning' (5) confirms focus on advertising and marketing rather than business strategy. However, research on guerrilla marketing and its effect on strategy business concept is crucial for company long term sustainability.

The word 'consumer' (23) is in the top five. Effect on customer is essential in communication and it is represented by 'behavior' (13), 'psychology' (5), 'preferences' (4) and 'opinion' (4). Unfortunately topics like 'attention', 'surprise' or 'diffusion' are neglected. Therefore research on consumer insides is desirable. There is a lot of literature about attention, surprise and diffusion generally but it mainly consists of experiments in controlled conditions.

Furthermore financial words as 'budget', 'costs', 'controlling' or 'revenue' are absent. It promotes the misconception that the guerrilla marketing is for free and low costs are matter of course. Levinson (2009) promotes guerrilla marketing as an inexpensive technique which requires time, energy and imagination. However mentioned essences are basically not for free. We can assume that research in this particular field is highly important for success in practice.

Co-word analysis (Table 2 annex) revealed three main points of interests. It should be stressed that the co-word analysis limitation is a subjective choice of the researcher in the certain steps of analysis. Choosing the topics of interests is one of them.

Firstly, there is, expectedly, high co-ocurance in the area of internet communication between words (internet, network, social, media, word of mouth), which highlights the results from frequency analysis. Accordingly, we can assume unconventional marketing communication in the digital environment as a hot topic. Unfortunately, there is a lack of research on smart phone, mobile and apps (applications for android operation system platform) guerrilla.

Secondly, as guerrilla marketing tends to be on the edge of moral and ethics, there is a very little connection between 'ethical' and 'internet', 'viral' ,'web' or 'buzz' (which were indicated as hot topic nowadays). From a strategic perspective, unethical marketing actions can harm company or product image while strengthen competitor which is completely opposite to guerrilla objectives. 
Finally, behavior tends to occur with the top listed in frequency analysis. This finding says that most of the general conception articles regularly deal with consumer behavior and then slightly fade out in the narrow topic articles. There is a certain white spot for the future research to conduct studies on consumer behavior on particular sub-tactics from the guerrilla marketing arsenal.

Figure 3: Histogram of issued articles about guerrilla marketing.

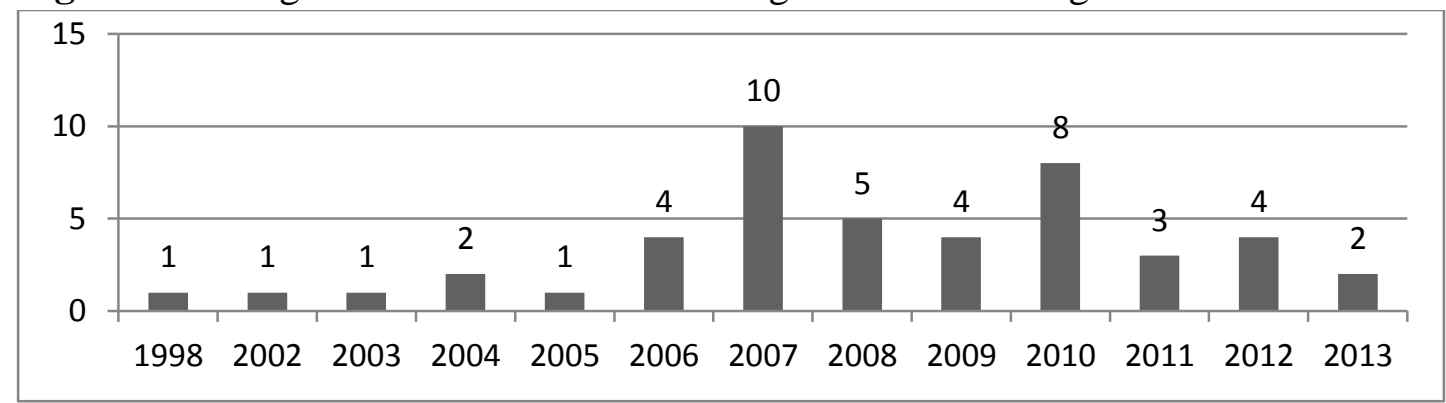

Source: Authors'own formulation based on data from Web of Science and EBSCO.

Figure 3 shows the development of issued articles in academic journals since 1984. However, the first reviewed article has been released in 1998. Since 2002 the number has been growing to meet the highest sum in 2007. It should be stressed that it is possible to expect some more articles by the end of 2013. We can see a slight reduction which is interesting because the topic has not been exhausted yet.

\section{Conclusion}

From the long term perspective in the marketing communication discipline there is question when guerrilla marketing becomes less effective. The answer depends on when it will become normality. Key factor of surprise and shock is in creating unexpected campaigns. There is possibility that particular tools of guerrilla marketing will suffer of clutter as we know it from TV advertising, banner blindness and so on. Guerrilla marketing is not a salvation tool. Company should always think about communication possibilities and how to analyze the current situation, consider its options and finally executives can make their own decision.

The main objectives of this paper were to review guerrilla marketing literature and find inaccuracies in theoretical field. Major inconsistencies were found in defining guerrilla marketing as a form of promotional activity rather than a complex marketing mix orientated strategy. In other words guerrilla marketing harmoniously complements traditional marketing mix giving marketers a new option how to differentiate through surprise and diffusion effects.

Proceeding analysis of the highly influent articles in the top journals gave an adequate image of the past and current state of knowledge. Firstly, the research on strategic dimension of guerrilla marketing campaigns and its consequences on long term relationship with public and prospective customers is required. Since some shocking guerrilla campaigns has been judged negatively by general public some articles containing best practice could help the marketing managers avoid such situations. Another managerial perspective which is underestimated in current research is budgeting, cost, revenues and controllability. Ability to measure cost and benefits of campaign is crucial for future development of the company.

Secondly, form the customer behavior perspective the future research on attention, surprise and diffusion effects of guerrilla marketing is possible. Results showed lack of articles on processing guerrilla campaign and its effects on consumer behavior. For example which 
incentives to use in which cases. Is it more suitable for promoting product or brand through guerrilla? Is there potential to engage the recipient and build a relationship through ambient marketing or event? What methods to use in the creative design of the campaign to secure intended reaction of the crowd? These and many other questions emerged from the performed analysis.

This paper revealed future research possibilities by frequency and co-word analysis and showed lack of concentration on strategy dimension, customer insides and financial aspects. Moreover there is a need for the proper categorization of guerrilla marketing tools since there is plenty of it. In other words, there are too many marketings while in fact marketing is only one. The author adopts an approach of the harmonic symbiosis between the conventional and unconventional marketing methods rather than dividing into the good and evil, black and white. At the end, the author would like to appeal to scholars and practitioners to stimulate discussion in the field of guerrilla marketing.

\section{References}

[1] ANSOFF, I., 1965. Corporate strategy. US: McGraw-Hill Inc. ISBN 978-0070021112.

[2] COULTER, N., I. MONARCH and S. KONDA, 1998. Software engineering as seen through its research literature: a study in co-word analysis. Journal of the American Society for Information Science, 49. ISSN 1532-2890.

[3] DING, Y., G. G. CHOWDHURY and S. FOO, 2001. Bibliometric cartography of information retrieval research by using co-word analysis. Information Processing \& Management, 37. ISSN 0306-4573.

[4] EGAN, J., 2007. Marketing communications. London: Thomson learning. ISBN 1844801217.

[5] HUGHES, M., 2006. Buzzmarketing: přimějte lidi, aby o vás mluvili. Praha: Management Press. ISBN 80-7261-153-4.

[6] HUTTER, K. and S. HOFFMANN, 2011. Guerrilla Marketing: The Nature of the Concept and Propositions for Further Research. Asian Journal of Marketing, 5, 39-54. ISSN 1819-1924.

[7] KAIKATI, A. M. and J. G. KAIKATI, 2004. Stealth Marketing: How to Reach Consumers Surreptitiously. California Management Review, 46, 6-22. ISSN 0008-1256.

[8] LEVINSON, J. C., 2009. Guerilla marketing. Brno: Computer press. ISBN 978-80-2512472-7.

[9] LINDSTRÖM, M., 2012. Vyluxované mozky: triky, které použivají firmy, aby nás přiměly k nákupu. Praha: Management Press. ISBN 978-80-7261-191-1.

[10] MALHOTRA, N. K., 1982a. Information load and consumer decision making. Journal of Consumer Reseach, 8, 419-430. ISSN 0093-5301.

[11] MUGHARI, A. M., 2011. Analysis of guerrilla and traditional marketing integration in improving the productivity of organizational marketing in enterprises in Iran: A case study of Kaveh Industrial Estate in Iran. African Journal of Business Management, 5, 944-948. ISSN 1993-8233.

[12] NUFER, G., 2013. Guerrilla Marketing - Innovative or parasitic marketing? Modern Economy, 4, 1-6. ISSN 2152-7245. 
[13] PAKSOY, T. and C. T. CHANG, 2010. Revised multi-choice goal programming for multi-period, multi-stage inventory controlled supply chain model with popup stores in Guerrilla marketing. Applied Mathematical Modelling, 34, 3586-3598. ISSN 0307-904X.

[14] PATALAS, T., 2009. Guerillový marketing. Praha: Grada. ISBN 978-80-247-2484-3.

[15] PORTER, M., 1985. Competitive advantage. New York: Free Press. ISBN 0-684-841460

[16] ROY, A. and S. P. CHATTOPADHYAY, 2010. Stealth marketing as a strategy. Business Horizons, 53, 69-79. ISSN 0007-6813.

[17] SCHULTE, T., 2007. Guerilla marketing für unternehmertypen. 3rd Edition. Sternenfels: Verlag Wissenschaft \& Praxis. ISBN 978-3896734358.

[18] SMITH, T., J. R. COYLE, E. LIGHTFOOT and A. SCOTT, 2007. Reconsidering models of influence: the relationship between consumer social networks and word-of-mouth effectiveness. Journal of advertising research, 47, 387-397. ISSN 0021-8499.

[19] TRANFIELD, D., D. DENYER, and P. SMART, 2003. Towards a metodology for developing evidence-informed management knowledge by means of systematic review. British Journal of Management, 14, 207-222. ISSN 1467-8551.

[20] ZUO, L. and S. R. VEIL, 2006. Guerrilla marketing and the Aqua Teen Hunger Force fiasco. Public Relations Quarterly, 51, 8-11. ISSN 0033-3700. 
Př́loha 1

Table 2: Co-word analysis of articles titles and keywords.

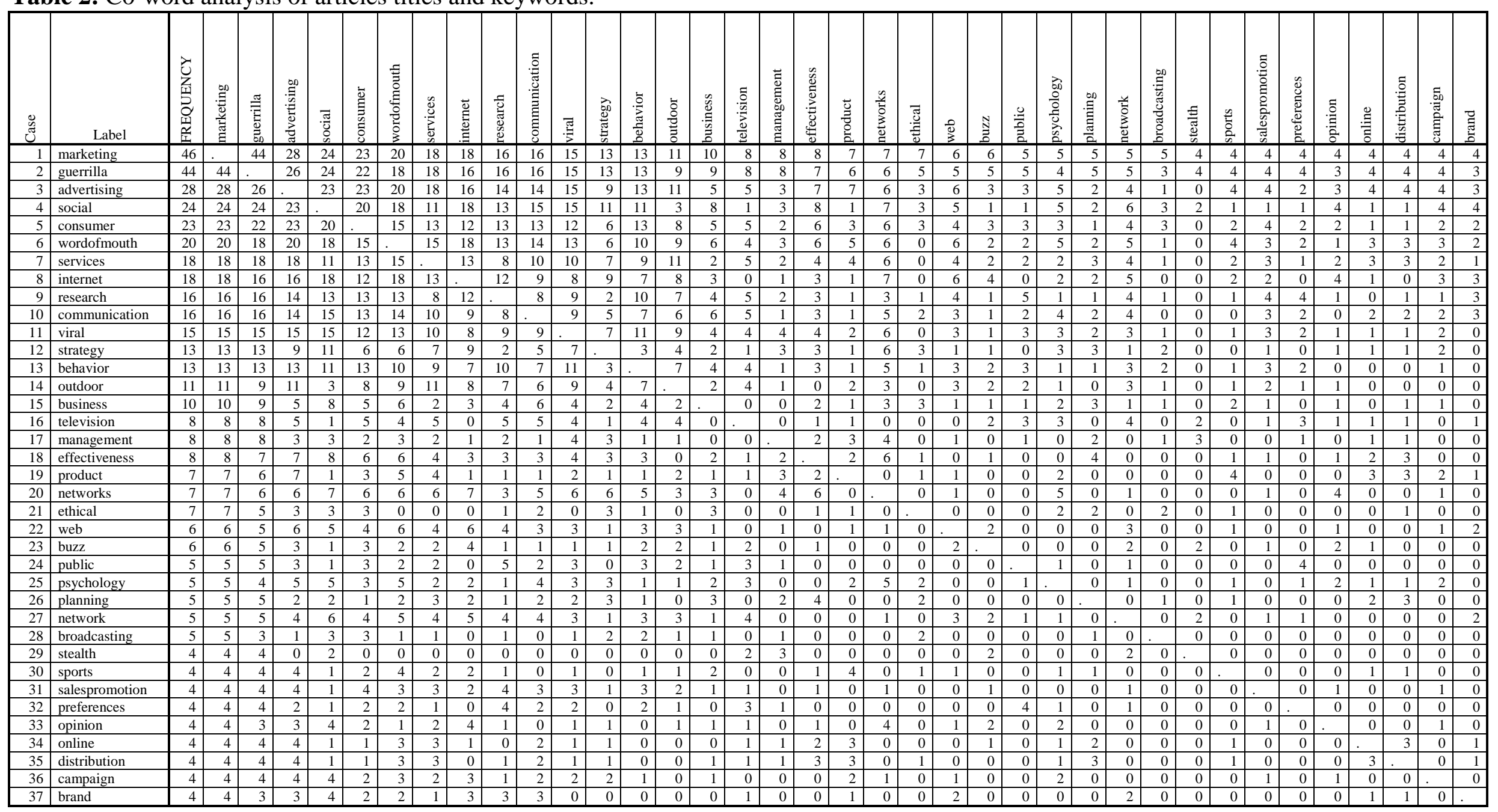

Source: Authors` own research. 